\title{
GEOGRAPHIC INFORMATION SYSTEM (GIS) APPLICATION TO ANALYZE LANDSLIDE PRONE DISASTER ZONE IN JEMBER REGENCY EAST JAVA
}

\author{
Fahmi Arif Kurnianto ${ }^{1}$, Elan Artono Nurdin ${ }^{2}$, Bejo Apriyanto ${ }^{3}$, Fahrudi Ahwan Ikhsan ${ }^{4}$
}

Rosmadi bin Fauzi ${ }^{5}$

$1,2,3,4$

Department of Geography Education, University of Jember, Indonesia

${ }^{5}$ Departement of Geography, University of Malaya, Kuala Lumpur, Malaysia

email: fahmiarif.fkip@unej.ac.id

DOI: $10.19184 /$ geosi.v2i1.752

Article History: Received Date $19^{\text {th }}$ February 2018, Received Revised $15^{\text {th }}$ March 2018, Accepted Date $25^{\text {th }}$ April 2018, Published Date $30^{\text {th }}$ April 2018

\begin{abstract}
Jember regency has several areas that are morphology of folding hills and mountain folds. The part of landslide prone zone is closely related to the slope of the slope. Areas with a sloping slope of more than $15^{\circ}$ need attention to the possibility of a landslide disaster. Interconnection contacts with weathering of rocks, settlements and land cover also affect the landslide potential. The existence of Ijen Volcano that produces volcanic rock deposits that are generally not yet unified will increase the potential for landslides in Jember Regency. Landslide has occurred one of them on Gunung Gumitir Street which is the main route of Surabaya-Jember-Banyuwangi traffic. In May 2016 this street is hit by landslide, so the flow of traffic through this lane is paralyzed and must be diverted to a further path, which rotates to Situbondo City. The transfer of this pathway resulted in a loss to the local community and who crossed the path. The occurrence of landslide disaster shows that Jember Regency area is vulnerable and potentially return to landslide. Therefore there is a need for a solution to solve this problem. One solution to solve the problem is by utilizing Geographic Information System (GIS) application. The purpose of this research is to analyze zonation prone to landslide in jember district. The design of the research is Geographic Information System overlay analysis. This design combines several parameters in the determination of landslideprone zones. This design combines several parameters in the determination of landslideprone zones. The parameter used in this research is (1) land use, (2) topography, and (3) soil.Based on the research results, it can be known zone with highest to lowest vulnerability level. Zone with very high level of vulnerability is located in Panti sub-district, Sumberbaru, Sukorambi, Dyke, Silo and Jelbuk. The zones have similar characteristics that include (1) soil type of andosol, (2) clay texture, (3) uncompacted rock, (4) slope of $30^{\circ}-40^{\circ}$ (steep and very steep), and (5) land use for settlements and plantations.
\end{abstract}




\section{INTRODUCTION}

Jember regency has several areas that are morphology of folding hills and mountain folds. The part of landslide vulnerability zone is closely related to the slope of the slope. Areas with a sloping slope of more than $15^{\circ}$ need attention to the possibility of a landslide disaster. Interconnection contacts with weathering of rocks, settlements and land cover also affect the landslide potential. The existence of Ijen Volcano that produces volcanic rock deposits that are generally not yet unified will increase the potential for landslides in Jember Regency.

The rainfall of Jember Regency is high. Rain occurs with a $50 \mathrm{~mm}$ long intensity (> 6 hours) causing an avalanche. Infiltration occurring on slopes with low vegetation cover will lead to greater avalanche potential. The area is also often occur. Rain that is not too dense, but run prolonged more than 1 or 2 days, so it will increase the chances of landslides occur. Jember regency has a diverse level of vegetation density. If the plant is dense and has a roots that can penetrate until the bedrock layer then the tubuhan will greatly serve as a retarder of the mass of the slope.

On the other hand even though plants have shallow roots but grow on soil layers that have strong cohesion power, the stability of the slopes will be strong. In certain cases plants that live on slopes with a certain slope actually acts as an addition to the load of slopes that encourage the occurrence of landslides. Landslide has occurred one of them on Gunung Gumitir Street which is the main route of Surabaya-Jember-Banyuwangi traffic. In May 2016 this street is hit by landslide, so the flow of traffic through this lane is paralyzed and must be diverted to a further path, which rotates to Situbondo City. The transfer of this pathway resulted in a loss to the local community and who crossed the path.

According to Sitorus (2006), landslide is a form of erosion whose transport or displacement occurs at a relatively short moment in an enormous volume. In contrast to other forms of erosion (erosion of sheets, furrow erosion, trench erosion) on landslide occurring at once in very short periods. Meanwhile, according to Dwiyanto (2002), landslide is a type of land movement, generally the land movement that occurs is avalanches and slumps / rotational slides. The forces of gravity and seepage (seepage) are the main cause of instability on natural slopes and slopes that are formed by excavation or stockpiling. The occurrence of landslide disaster shows that Jember Regency area is vulnerable and potentially return to landslide. Therefore there is a need for a solution to solve this problem. One solution to solve the problem is by utilizing Geographic Information System (GIS) application. 
GIS is designed to collect, store, and analyze objects and phenomena in which geographical location is an important or critical characteristic to be analyzed (Prahasta, 2009: 116). GIS application has several advantages that can be used to analyze zonation prone to landslides. These advantages include: (1) can analyze various data related to landslide disaster (geological data, slope, rainfall, vegetation, land use, and population density), (2) tool making costly and relative time (3) updating of data contained in the tool also takes a short time, and (4) The tool has comprehensive information, so the accuracy level can be accounted for.

Zonation analysis prone to landslide needs to be done because there are many factors that influence the occurrence of landslide area of Jember regency. This analysis is expected to reduce the number of landslide victims in the area. Based on the background of the above issues the authors are interested to take the title "Utilization Geographic Information System (GIS) in Analyzing Landslide Avalanche in Jember District". This study aims to utilize Geographic Information System (GIS) in analyzing zonation prone to landslides in jember district.

According to Naryanto (2002), landslide based on speed consists of 5 types, namely:

1. Streams, landslides move in unison or suddenly at high speed.

2. Avalanches, avalanche material moves slowly with the former horseshoe-shaped landslide.

3. Collapse, generally avalanche material in the form of stone and soil move quickly to very fast on a cliff.

4. Compound, avalanches that develop from collapse or landslides and progress further into streams.

5. Amblesan (land subsidence), occurring in underground mining, excessive ground water suctioning, soil erosion process and in soil compaction process.

The decrease of land occurs due to consolidation, ie the decrease of ground level due tochanges in the volume of a soil layer. This process can take place more quickly if there is a loading that exceeds the carrying capacity of the soil or excessive and excessive groundwater extraction. Excessive groundwater retrieval may lead to a decrease in groundwater (in deep ground water aquifer systems), whereas the pressure between stones increases.

According to Aronoff (1998), SIG is a computer-based system used to store and manipulate information. GIS is a computer-based system that has 4 capabilities to handle geographically referenced data such as: (a) input, (b) data management (data storage and retrieval), (c) data analysis and manipulation and (d) output. 


\section{METHODS}

The design of the research is Geographic Information System overlay analysis. This design combines several parameters in the determination of landslide-prone zones. This design combines several parameters in the determination of landslide-prone zones. The parameter used in this research is (1) land use, (2) topography, and (3) soil. the following is a research design scheme.

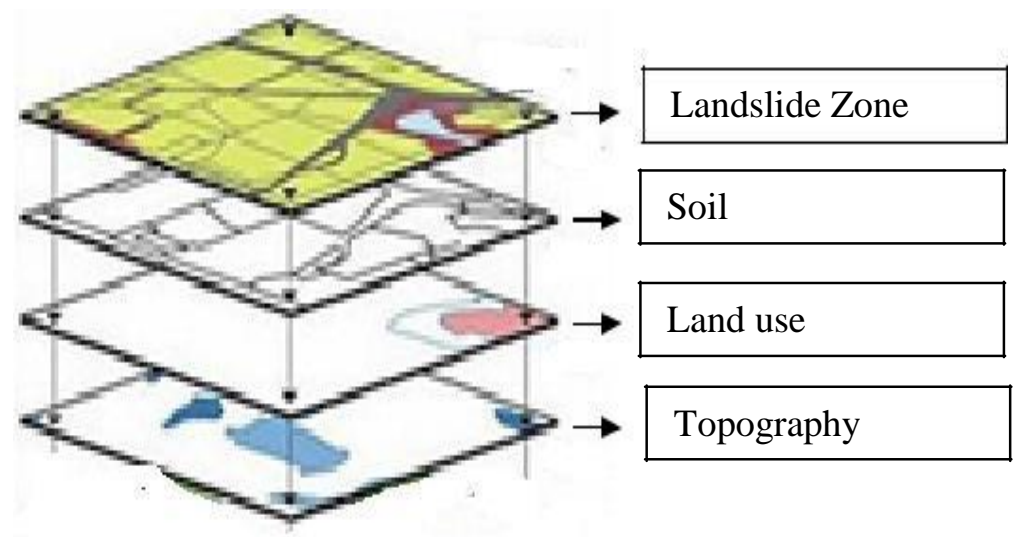

Figure 1. Overlay Analysis

Data analysis technique used in this research is the overlay and buffer analysis that exist in Geographic Information System (GIS). The overlay analiysis serves to accumulate all the parameters used in the study. The buffer analysis is used to determine the furthest distance of an area affected by a landslide disaster.

Data collected in the form of spatial data and attribute data (rainfall data) obtained from several Meteorology, Climatology and Geophysics Agency. Observations were also made at the landslide location in the study area. The map data collected are as follows:

a) Digital map of Jember District 1: 100,000 administrative territory obtained from Geospatial Information Agency (BIG).

b) Digital map of Land Type of Jember Regency Scale 1: 100,000 obtained from Geospatial Information Agency (BIG).

c) Digital Geology Map of Jember Regency Scale 1: 100,000 obtained from Geological Agency.

e) Digital maps of Jember Regency use Scale 1: 100,000 from landsat imagery 
h) Digital Rainfall Map of scale 1: 100.000 Kabupaten Jember obtained from Meteorology, Climatology and Geophysics Agency.

i) Digital maps of 1: 100.000 scale of Slopes of Jember Regency is obtained from the Regional Development Planning Board of Jember Regency.

\section{RESULTS AND DISCUSSION}

\section{Results}

Field data collection is done directly through survey and direct observation (observation), interviews, and documentation to record physical properties in the field. Field observation and data collection is done after the factors causing the landslide can be identified. The process of identifying and selecting the parameters observed based on the condition of the research area and the results of the literature review. In this case theoretical considerations (the results of literature studies) and factors of physical condition of the region. Here is the result of GIS analysis using overlay method.

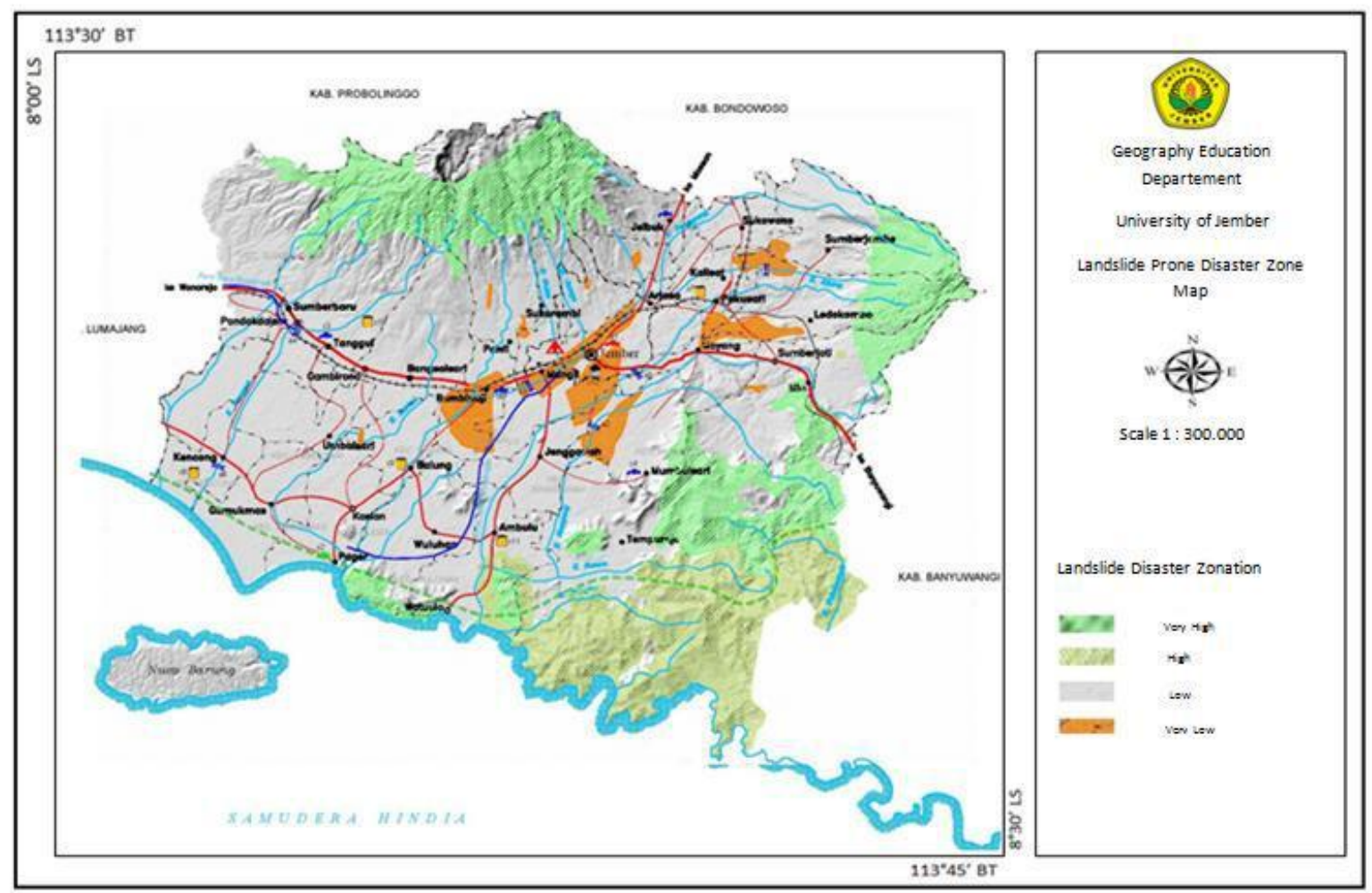


Based on the research results, it can be known zone with highest to lowest vulnerability level. Zone with very high level of vulnerability is located in Panti sub-district, Sumberbaru, Sukorambi, Dyke, Silo and Jelbuk. The zones have similar characteristics that include (1) soil type of andosol, (2) clay texture, (3) uncompacted rock, (4) slope of $30^{\circ}-40^{\circ}$ (steep and very steep), and (5) land use for settlements and plantations.

\section{Discussion}

The most influential factors into the zonation with a very high level of vulnerability is settlements. The settlements built in the zone resulted in low pearmebilitas and porosity of the soil. As a result, the area has a run-off that is not matched by the ability of the land to flow. The existence of the run-off also erodes the soil organic matter, causing the slope to have a considerable load in accommodating run off. This is what causes the region into the zoning with very high landslide vulnerability level.

Zone with high level of vulnerability is located in District Tempurejo. The zones have characters that include (1) soil andosol types, (2) clay textures, (3) uncompacted rocks, (4) slope of $30^{\circ}-40^{\circ}$ (steep and very steep), and (5) land use for forests with little settlement. Factors that contribute the largest so that the region into the zonation with high levels of vulnerability of the existence of settlements. The settlements built in the zone resulted in reduced pearmebilitas and porosity of the soil. As a result, the area has a run off that has the potential to make the slopes become water saturated. The existence of run off also erodes the soil organic matter, resulting in slopes have a large enough load in accommodating run off. This causes the region to enter into zonation with high landslide vulnerability levels.

A zone of low vulnerability lies in almost all districts. The zone has a character that includes (1) inceptisol soil type, (2) clay texture, (3) compact rock, (4) slope of $2^{0}-4^{0}$ (flat), and (5) land use for settlements.The factor that gives the largest contribution so that the region goes into zonation with low level of vulnerability ie slope of the slope. The settlements built in the zone are in accordance with the spatial designation of the area. Flat areas, have a suitability to be developed into residential and economic centers of the population. The area has a run off that must be regulated with the correct water spatial principle to avoid high sedimentation in water bodies.

The existence of the run off also reduces the pearmebility of the soil, but will not cause a landslide due to the absence of steep slopes. A zone with very low levels of vulnerability lies in almost all districts. The zone has a character that includes (1) inceptisol soil type, (2) clay texture, (3) compact rock, (4) slope of $2^{0}-4^{0}$ (flat), and (5) land use for settlements. 
The most influential factors into the zonation with very low levels of vulnerability that is the slope of the slope and land use. The settlements built in the zone are in accordance with the spatial designation of the area. In addition, this zone is the center of economic activity of Jember Regency, so almost all buildings meet the standards of good environmental management.

\section{CONCLUSION}

Zoning of landslide disaster areas in Jember Regency consists of very high, high, low, and very low zones. Land use factor for settlement gives the biggest contribution in high landslide vulnerability in Jember Regency. It is also related to the concept of disaster that is always associated with community activities.Zoning can be used as a reference for the community to be more concerned about the environment. People can know the important factors. Knowledge kebencaaan it will reduce the level of vulnerability landslide disaster in Jember regency.

\section{REFERENCES}

Dwiyanto, J. S., 2002. Penanggulangan Tanah Longsor dengan Grouting. Semarang: Pusdi Kebumian LEMLIT UNDIP.

Naryanto, N.S. 2002. Evaluasi dan Mitigasi Bencana Tanah Longsor di Pulau Jawa Tahun 2001. BPPT: Jakarta.

Prahasta. Eddy, 2009. Sistem Informasi Geografis. Bandung : Penerbit Informatika

Sitorus, S. R. P., 2006. Pengembangan Lahan Berpenutupan Tetap Sebagai Kontrol Terhadap Faktor Resiko Erosi dan Bencana Longsor. Direktorat Jenderal Penataan Ruang Departemen Pekerjaan Umum: Jakarta.

Arends, Richard I. 2008. Learning to Teach (Belajar Untuk Mengajar). Yogyakarta: Pustaka Pelajar.

Huda, Miftahul. 2011. Cooperative Learning. Yogyakarta: Pustaka Pelajar.

Jacksen, Sherri L. 2011. Research Methode: Moduler Approach. Stamford:

Cengage Learning.

Joyce, Bruce and Beverly Showers. 2002. Student Achievement Through Staff Development.Alexandria: ASCD.

Mushodik. 2013. Pengaruh Model Pembelajaran Group Investigation terhadap Kemampuan Berpikir Kritis Mahasiswa Madrasah Aliyah Negeri 6 Jakarta. Tesis tidak diterbitkan. Malang: PPS Universitas Negeri Malang. 
Pintrich, R. Paul .Et al. 1991. A Manual for The Use of The Motivated Strategies for Learning Questionnaire.Ann Arbor, Michigan : National Center for Research to Improve Postsecondary Teaching and Learning.

Rusman. 2012. Model-Model Pembelajaran. Jakarta: Raja Grafindo Persada.

Sharan, Shlomo. 2014. Handbook of Cooperative Learning. New York: Teachers College Press.

Slavin, Robert E. 2005. Cooperative Learning: theory, research and practice

(N. Yusron. Terjemahan). London: Allymand Bacon. Buku asli diterbitkan tahun 2005.

Sumarmi. 2012. Model-Model Pembelajaran Pendidikan Lingkungan Hidup. Malang : Aditya Media Publishing.

Tan, Ivy Geok Chin. 2004. Effects of cooperative learning with group investigation on secondary students' achievement, motivation and perceptions. Singapore: National Institute of Education.

Trianto. 2007. Model-model Pembelajaran Inovatif Berorientasi Konstruktivistik. Jakarta: Prestasi Pustaka.

Ulfah, Restu. 2014. Pengaruh Model Pembelajaran Group Investigation terhadap Hasil Belajar Mahasiswa Pendidikan Lingkungan Hidup Mahasiswa Negeri 1 Banjarbaru. Tesis tidak diterbitkan. Malang: PPS Universitas Negeri Malang.

Uno, Hamzah. 2008. Model Pembelajaran, Menciptakan Proses Belajar Mengajar yang Kreatif dan Efektif. Jakarta: Bumi Aksara. 
Dwiyanto, J. S., 2002. Penanggulangan Tanah Longsor dengan Grouting. Semarang: Pusdi Kebumian LEMLIT UNDIP.

Naryanto, N.S. 2002. Evaluasi dan Mitigasi Bencana Tanah Longsor di Pulau Jawa Tahun 2001. BPPT: Jakarta.

Prahasta. Eddy, 2009. Sistem Informasi Geografis. Bandung : Penerbit Informatika

Sitorus, S. R. P., 2006. Pengembangan Lahan Berpenutupan Tetap Sebagai Kontrol Terhadap Faktor Resiko Erosi dan Bencana Longsor. Direktorat Jenderal Penataan Ruang Departemen Pekerjaan Umum: Jakarta. 
